\title{
Surgery versus stereotactic body radiation therapy for operable stage I non-small cell lung cancer: Can we achieve equipoise?
}

\author{
Mark W. Onaitis, MD, ${ }^{a}$ and Joseph Salama, $\mathrm{MD}^{\mathrm{b}}$
}

\author{
From the Departments of ${ }^{\text {a Surgery and }}{ }^{\mathrm{b}}$ Radiation Oncology, Duke University Medical Center, Durham, NC. \\ Disclosures: Authors have nothing to disclose with regard to commercial support. \\ Received for publication April 1, 2016; accepted for publication April 1, 2016. \\ Address for reprints: Mark W. Onaitis, MD, DUMC Box 3305, Durham, NC 27710 (E-mail: mwo@ duke.edu). \\ J Thorac Cardiovasc Surg 2016;152:1-2 \\ $0022-5223 / \$ 36.00$ \\ Copyright (C) 2016 Published by Elsevier Inc. on behalf of The American Association for Thoracic Surgery \\ http://dx.doi.org/10.1016/j.jtcvs.2016.04.016
}

In the current issue of the Journal, Rosen et $\mathrm{al}^{1}$ present an impressive analysis of the National Cancer Database, comparing outcomes of clinical stage I non-small cell lung cancer (NSCLC) patients free of comorbidities undergoing either lobectomy or stereotactic body radiation therapy (SBRT). The 13,562 patients who underwent lobectomy enjoyed a significant survival advantage over the 1781 patients who underwent SBRT (hazard ratio 0.38 for overall survival). When matched for propensity to undergo lobectomy and SBRT, patients with early-stage lung cancer (1781 patients in each group), surgery patients had a 59\% 5-year survival compared with $29 \%$ for SBRT.

The results of the current study match those of previous analyses that use the National Cancer Database and other databases. $^{2-5}$ Although the obvious limitation of this analysis is its retrospective nature, the authors attempted to control bias by excluding patients not offered surgery for health-related reasons, including only patients without comorbidities, and performing the propensity model. These represent significant improvements over the previously published analyses, although it may be impossible in a retrospective database to identify patients with SBRT truly without comorbidity.

Although results such as these should clearly continue to push clinicians to consider lobectomy for fit patients with medically operable stage I NSCLC, such retrospective studies will not represent the final word on SBRT. Unfortunately, prospective trials have failed to accrue. Equipoise for a comparison of SBRT and lobectomy, however, is achievable, as a pooled analysis of the very few randomized patients has demonstrated improved survival in the SBRT group.

The key issue critical to achieving equipoise is ensuring all patients with medically operable stage I NSCLC have appropriate lymph node assessment. In the current analysis, only $6 \%$ of patients with SBRT had a pathologic assessment of lymph nodes. Almost assuredly, undiagnosed lymph node metastases are the primary culprits responsible for the poor survival of the SBRT group. The lack of pathologic nodal staging deprives medically operable patients

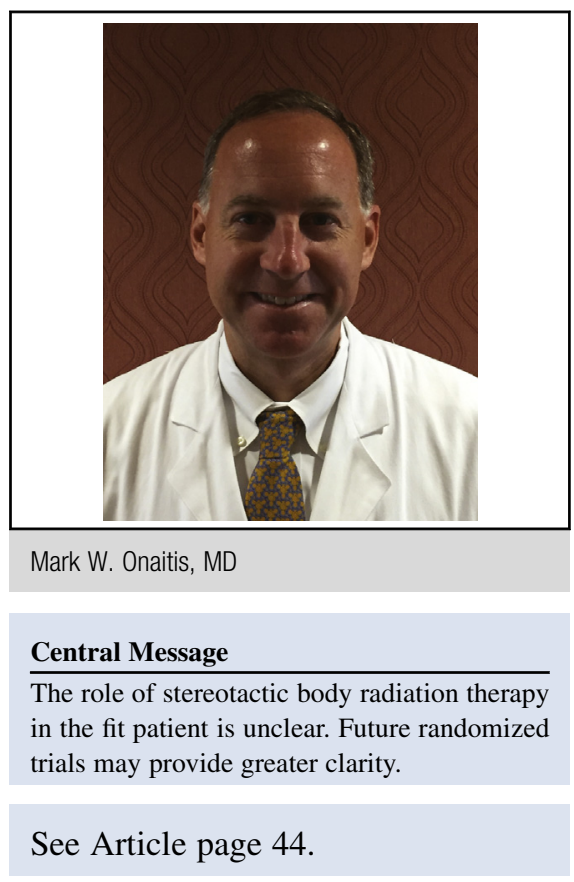

receiving SBRT from the known survival improvement of adjuvant chemotherapy. Hopefully, future trials examining lobectomy versus SBRT in healthy patients will include mandatory assessment lymph nodes in both arms. The upcoming VALOR (Veterans Affairs Lung cancer surgery Or stereotactic Radiotherapy) includes mandatory pathologic assessment of any suspicious lymph nodes (including any lymph node $>10 \mathrm{~mm}$ with standardized uptake value $>2.5$ ) seen on fludeoxyglucose-positron emission tomography/computed tomography. Stablemates (ClinicalTrials. gov ID NCT02468024) has similar requirements. Although these recommendations focus on mediastinal nodes, navigational bronchoscopy and radial endobronchial ultrasound will allow assessment of N1 lymph nodes that lobectomy routinely resects.

To provide each lung cancer patient with the best opportunity for cure while minimizing morbidity and mortality, identifying those patients who will benefit from each treatment is of the utmost importance. Clearly, the excellent local control achieved with SBRT makes it an attractive noninvasive treatment for patients without lymph node metastases. If surgeons, radiation oncologists, and the entire multidisciplinary treatment team together can make every effort to ensure that truly N0 patients are included in prospective randomized studies, then 
equipoise should be achievable so that we can answer these important questions.

\section{References}

1. Rosen JE, Salazar MC, Wang Z, Yu JB, Decker RH, Kim AW, et al. Lobectomy versus stereotactic body radiotherapy in healthy patients with stage I lung cancer. J Thorac Cardiovasc Surg. 2016;152:44-54.

2. Puri V, Crabtree TD, Bell JM, Broderick SR, Morgensztern D, Colditz GA, et al. Treatment outcomes in stage I lung cancer: a comparison of surgery and stereotactic body radiation therapy. J Thorac Oncol. 2015;10:1776-84.
3. Grills IS, Mangona VS, Welsh R, Chmielewski G, McInerney E, Martin S, et al Outcomes after stereotactic lung radiotherapy or wedge resection for stage I non-small-cell lung cancer. J Clin Oncol. 2010;28:928-35.

4. Mokhles S, Verstegen N, Maat AP, Birim Ö, Bogers AJ, Mokhles MM, et al. Comparison of clinical outcome of stage I non-small cell lung cancer treated surgically or with stereotactic radiotherapy: results from propensity score analysis. Lung Cancer. 2015;87:283-9.

5. Chang JY, Senan S, Paul MA, Mehran RJ, Louie AV, Balter P, et al. Stereotactic ablative radiotherapy versus lobectomy for operable stage I non-small-cell lung cancer: a pooled analysis of two randomised trials. Lancet Oncol. 2015;16: 630-7.

Access to The Journal of Thoracic and Cardiovascular Surgery Online is reserved for print subscribers!

Full-text access to The Journal of Thoracic and Cardiovascular Surgery Online is available for all print subscribers. To activate your individual online subscription, please visit The Journal of Thoracic and Cardiovascular Surgery Online, point your browser to http://www.mosby.com/jtcvs, follow the prompts to activate your online access, and follow the instructions. To activate your account, you will need your subscriber account number, which you can find on your mailing label (note: the number of digits in your subscriber account number varies from 6 to 10 ). See the example below in which the subscriber account number has been circled:

\section{Sample mailing label}

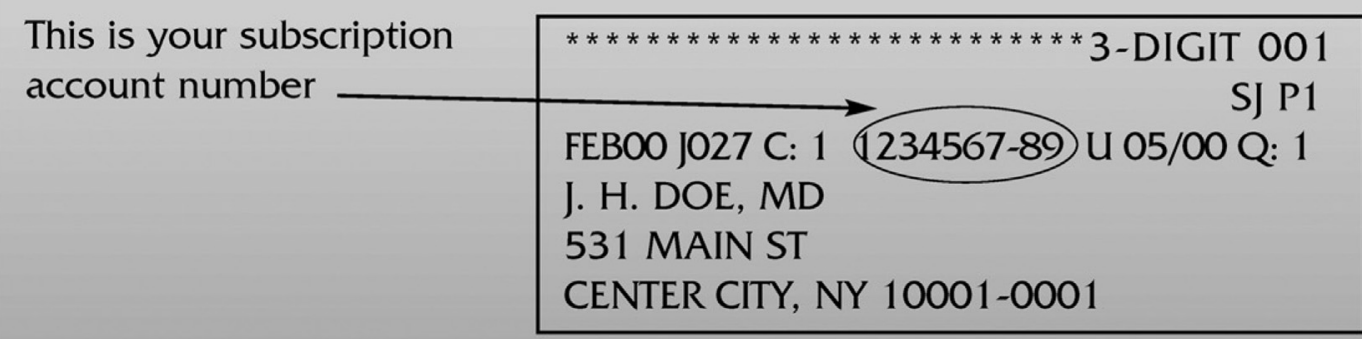

Personal subscriptions to The Journal of Thoracic and Cardiovascular Surgery Online are for individual use only and may not be transferred. Use of The Journal of Thoracic and Cardiovascular Surgery Online is subject to agreement to the terms and conditions as indicated online. 